\title{
КОММЕНТАРИЙ ЗАКОНОДАТЕЛЬСТВА
}

\author{
Кузнецова Т.В., Кузнецова О.А.
}

\section{РЕЙДЕРСКИЕ ЗАХВАТЫ КАК РАЗНОВИДНОСТЬ ЭКОНОМИЧЕСКИХ ПРЕСТУПЛЕНИЙ: РRО ЕТ СОNTRА}

Аннотация: Долгий спор о защите интересов собственников бизнеса от рейдерских захватов решён путём введения в действующий уголовный закон нескольких статей за соответствующие преступные действия. Большинство данных норм-новелл находятся в главе 22 Уголовного кодекса РФ и официально признаются преступлениями в сфрере экономической деятельности. Анализ содержания уголовно-правовых положений о рейдерских захватах позволяет усомниться и в избранном виде объекта уголовно-правовой охраны, и в необходимости криминализации данных действий. Методологической основой исследования явился исторический анализ, метод сравнительного анализа, метод деления понятий, системный и статистический методы. Основными выводами проведенного исследования являются:1. анализ содержания уголовно-правовых положений о рейдерских захватах позволяет усомниться и в избранном виде объекта уголовно-правовой охраны, и в необходимости криминализации данных действий;2. необходимы разъяснения Пленума Верховного Суда РФ об особенностях применения рассматриваемых норм.

Ключевые слова: Экономические преступления, объект уголовно-правовой охраны, интересы государственной власти, уголовная ответственность, рейдерские захваты, регламентация рейдерских действий, рейдерство, криминальный захват бизнеса, международное финансирование, хозяйствующий субъект.

Review: The long dispute over the protection of business owners' rights in the cases of illegal takeovers of business has been solved by amending the current criminal law with several articles, which provide punishment for such criminal actions. Most legal novels of this kind are contained in the chapter 22 of the Criminal Code of the Russian Federation, and are officially recognized as crimes in the economic sphere. The analysis of regulatory provisions on illegal takeovers gives the reason for doubts both in the chosen form of the object of legal protection, and in the necessity to criminalize such actions. The research methodology is based on the historical analysis, comparative analysis, the method of division of notions, the system and statistical methods. The author concludes that: 1. the analysis of regulatory provisions on illegal takeovers gives the reason for doubts both in the chosen form of the object of legal protection, and in the necessity to criminalize such actions; 2 . the commentaries of the Plenum of the Supreme Court of the Russian Federation on the peculiarities of application of these provisions are necessary. 
Keywords: Economic crime, object of legal protection, interests of public authority, criminal liability, illegal takeover, regulation of illegal takeovers, illegal takeover, illegal takeover, international financing, economic entity.

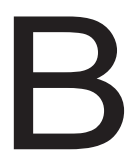

опросы уголовно-правовой регламентации рейдерских захватов бизнеса довольно широко обсуждались в научной литературе, начиная с 2003-2005гг. К настоящему времени интерес к преступлениям рейдерского характера уменьшился в виду включения в отечественное уголовное законодательство ряда норм об ответственности за совершение соответствующих махинаций на фондовом рынке, с документацией депозитарного учёта, реестрами акционеров, равно как и за совершение иных действий, направленных на неправомерное получение имущественных прав на активы хозяйствующего субъекта. Между тем анализ положений уголовно-правовых новелл в этой части позволяет усомниться в правильности признания большинства «рейдерских» преступлений в качестве разновидности преступлений в сорере экономической деятельности, равно как и целесообразности их криминализации.

История рейдерства уходит корнями в эпоху Нового времени, когда Британское королевство претендовало на неограниченное господство в мировом океане. Тогда в составе английского флота находились специальные корабли, целью которых являлось уничтожение торговых судов иностранных государств, осуществляющих наряду с Англией политическую экспансию в странах Азии и Америки. Эти суда именовались «рейдерами» (захват, налёт), а их, в принципе, пиратская деятельность рассматривалась в качестве разновидности государственной службы [6. С.3-4].

В более позднее время термин «рейдерство» стал характеризовать поглощение юридического лица более крупной корпорацией в рамках законной экономической деятельности. Противоправность данных действий состояла в том, что подобная реорганизация проходила против или помимо воли собственника поглощаемой организации, который в силу искусственно созданных экономических проблем не мог противодействовать захвату своего бизнеса представителями организации-рейдера. Принципиально, рейдерская схема причинения вреда хозяйствующему субъекту не изменилась.

Объективно, реорганизация хозяйствующих субъектов является одним из гражданско-правовых институтов, а потому перечисленные выше действия априори рассматриваются как правомерные. В этой связи различия законной и общественно опасной реорганизацией хозяйствующих субъектов, прежде всего, заключаются в целях совершения данных юридически значимых действиях. Компания-рейдер в подавляющем большинстве случаев преследует корыстные цели, связанные с обогащением за счёт поглощаемого юридического лица. Ведение бизнеса, уплата долгов по заработной 
плате, налогам, увеличение штата сотрудников и т.п. - всё это находится в плоскости среднесрочной и долгосрочной перспективы, а потому не интересует злоумышленника, стремящегося как можно скорее получить имущественную выгоду от осуществлённой махинации. Именно в этом видится и общественная опасность рейдерской деятельности: отсутствие должной защиты интересов хозяйствующих субъектов в этой части может породить увеличение числа безработных граждан, разрыв экономических связей, дефицит бюджета и иные негативные последствия экономического характера.

Рейдерство, несмотря на многочисленные предложения, официального определения не получило. Из всех вариантов дефиниций данного явления, предложенных в научной литературе, в качестве одного из самых удачных можно назвать сорормулированное Н.А. Лопашенко: тщательно спланированная система деятельности, направленная на получение чужой компании, осуществляющей предпринимательскую и (или) иные виды экономической деятельности [5. С.7-8]. В.Ф. Лапшин, проведя исследование по данной проблематике, предложил небезынтересный вариант генезиса отечественного уголовного законодательства о регламентации рейдерских действий. Так, данным автором выделены три этапа, первым из которых пришёлся на 19851997гг. - время приватизации и становления рыночной экономики. Наиболее популярным видом криминального воздействия на хозяй- ствующего субъекта в данный временной период было совершение в отношении собственников юридических лиц и их представителей различных насильственно-корыстных преступлений: вымогательство, разбой, причинение телесных повреждений различной степени тяжести и убийство [3].

Периодом с 1998г. по 2003г. обозначается второй этап российской истории криминального захвата бизнеса. Государство в эти годы испытывало существенные фринансовые трудности, вызванные как внутригосударственным экономическим кризисом (неспособность выполнения ГКО и дефолт 1998 года), так и последующими проблемами с возвратом долгов таким субъектам международного фринансирования. Тогда многие предприятия, осуществляющие производственную деятельность, испытывали фринансовые трудности не только по расчётам с контрагентами и уплатой обязательных платежей в бюджетную систему страны, но и по заработной плате. Этим успешно пользовались злоумышленники, которые, действуя, как правило, от лица различных фринансово-промышленных групп и холдингов, ликвидировали задолженность интересующего их субъекта и фрактически становились единственными или главными кредиторами организации-должника. После этого инициировалась процедура банкротства хозяйствующего субъекта, в результате которой активы переводились в собственность злоумышленника, а задолженность перед бюджетом списывалась в связи с юридической ликвидацией органи- 
зации-должника. Данное явление в отечественной экономике получило такое широкое распространение, что позволило представителям высших органов государственной власти сравнить гражданско-правовой институт банкротства с одним из противоправных средств передела собственности [7].

Третий этап развития рейдерской деятельности в России определяется, приблизительно, с 2004 года и длится по настоящее время. Отличительной чертой рейдерской деятельности этого периода времени является то, что в отличие от предыдущих видов осуществления преступной деятельности, злоумышленники, в принципе, не вмешиваются в экономическую деятельность интересующего их юридического лица. Здесь исключаются любые варианты запрещённого уголовным законом корыстно-насильственного воздействия на собственников (участников) юридического лица и (или) их представителей. Средством совершения общественно опасных действий, направленных на захват имущественных активов организации, является совершение сделок по незаконному приобретению ценных бумаг организации, долей в уставном капитале, мошеннические манипуляции с реестром акционеров и проч. [9. С.111-112]. В результате подобных действий злоумышленник формально получает право на единоличное управление интересующей его организацией [4].

Что касается уголовного законодательства, то оно не всегда предусматривало в названные периоды времени средства противодействия криминальному захвату собственности хозяйствующего субъекта. Рейдерские действия, совершаемые, преимущественно, в 19851997 гг., квалифицировались, в основном, по ст. 163, 162 и, реже, - по ст. 179, 201 и 330 УК [8]. Характерные для второго этапа (1998-2003 гг.) общественно опасные посягательства подпадали под действие уголовно-правовых норм, устанавливающих ответственность за криминальные банкротства и уклонение от уплаты налогов: ст. 195-199² УК [2]. Средства захвата бизнеса, которые используются рейдерами, приблизительно, с 2004 года, не предусматривались в уголовном законе в качестве преступных посягательств вплоть до 2010 года. К наиболее распространенным некриминальным действиям, сопряженным с захватом бизнеса или с «недружественным поглощением» юридического лица-потерпевшего, относятся: 1) недобросовестная реализация акционерами своих прав, что может выражаться в смене руководства общества с нарушением норм корпоративного права, блокирование деятельности общества, блокирование контрольного пакета акций и др.; 2) неправомерное завладение акциями общества, которое совершается в результате хищения в соучастии с профессиональным участником рынка ценных бумаг, принуждения акционеров к продаже принадлежащих им акций, скупка акций, выпуск которых не прошел государственную регистрацию и др.; 3) вывод активов общества путем заключения различных договоров, по которым организация 
обязуется передать принадлежащее ей на праве собственности имущество контрагентам [4].

Официально вопрос о специальной уголовно-правовой регламентации рейдерства был поставлен руководством Федеральной службы по фондовым рынкам в 2006 году. Позже с аналогичными инициативами выступали Следственный комитет, Генеральная прокуратура, МВД и др. Необходимость внесения соответствующих дополнений в уголовное законодательство обосновывалась, преимущественно, высокой общественной опасностью рейдерской деятельности и отсутствием надлежащих правовых механизмов привлечения злоумышленников к ответственности за причинение вреда имущественным интересам собственников хозяйствующих субъектов и участников фондовых рынков. В 2006 году был представлен законопроект об уголовной ответственности за ненасильственные рейдерские захваты имущественных прав хозяйствующих субъектов, их собственности в следствие совершения противоправных действий с акциями хозяйственных обществ, фальсификации решений коллегиальных органов управления организацией и проч. [1]. На основе этого законопроекта подготовлен Федеральный закон от 01.07.2010г. №147-Ф3, которым российский уголовный закон дополнялся ст. 1701: «Фальсификация единого государственного реестра юридических лиц, реестра владельцев ценных бумаг или системы депозитарного учета», 1855: «Фальсификация решения общего собрания акционеров (участников) хозяйственного общества или решения совета директоров (наблюдательного совета) хозяйственного общества», 2853: «Внесение в единые государственные реестры заведомо недостоверных сведений», а также ч. 3 ст. $185^{2}$, предусматривающая ответственность за внесение в реестр владельцев ценных бумаг недостоверных сведений, за уничтожение или подлог документов, на основании которых вносятся изменения в реестр владельцев ценных бумаг.

Формально все преступления, предусмотренные нормами «антирейдерского» законодательства, относятся к преступлениям в сфрере экономической деятельности, так как размещены в составе гл. 22 УК РФ (кроме ст. $285^{3}$ ). Но, как справедливо отмечается в научной литературе, подобный подход к определению сущности рейдерских преступлений не способствует их отграничению от иных групп преступлений, совершаемых в сфрере экономики. При широком подходе к определению сущности рейдерских преступлений к ним могут быть отнесены отдельные преступления против и собственности, и интересов государственной власти, и порядка управления [1. С.86-88]. Приведённая точка зрения далеко небезосновательна, а потому определение специфических черт преступлений, включаемых в группу рейдерских, становится достаточно затруднительным.

В свою очередь обозначение рейдерских преступлений именно в таком формате несколько уязвимо и с позиции обоснования криминализации. Даже при осуществлении поверхностного юридического анализа содержания перечисленных 
норм можно констатировать, что перечисляемые в них деяния являются вариантами приготовительных к совершению хищения действий. Поэтому выявление всех юридически значимых признаков составов рассматриваемых преступлений могло бы создавать все необходимые предпосылки для квалификации неоконченного хищения имущества юридических лиц или физических лиц - инвесторов. По этой причине вряд ли следовало дополнять действующий УК РФ значительным количеством норм, содержание которых вызывает объективные трудности толкования в процессе правоприменительной деятельности. В сложившихся условиях данная проблема гораздо эффрективней могла бы быть решена путём дачи Пленумом Верховного Суда РФ разъяснений об особенностях применения норм гл. 21 УК РФ, а равно ст. 292 и 327 УК РФ, в случаях совершения рейдерских действий в отношения имущества и (или) имущественных прав хозяйствующих субъектов.

\section{Библиография:}

1. Алексеев Ю.Ф. О результатах работы органов предварительного следствия МВД России по противодействию рейдерским захватам // Недвижимость и инвестиции. Правовое регулирование. 2009. № 1. с. 11 // URL: http://dpr.ru/journal/journal_36_17.htm (дата обращения: 26.10.2015).

2. Кузнецова Т.В. Некоторые аспекты рейдерства // Тенденции и перспективы развития уголовного и уголовно процессуального законодательства в борьбе с преступностью: Материалы Всероссийской научной конференции, посвященной памяти проф. Б.С. Волкова. М.: РУДН, 2011. С. 111-116.

3. Лапшин В.Ф. Преступления против интересов инвесторов. М.: РИОР, 2014. 127 с.

4. Лапшин В.Ф.Экономические и рейдерские преступления: правовое содержание и вопросы соотношения // Российское правосудие. 2014. № 12. С. 82-88.

5. Лопашенко Н. «Рейдерство» // Законность. 2007. № 4. С. 7-12.

6. Можейко И.В. Пираты, корсары, рейдеры. М.: Аванта +, 2010. 416 с.

7. Слободянюк Д. Владимир Путин предотвратил новую волну «нецивилизованного захвата собственности» // Правда. 2002. 6 авг. С. 5.

8. Тормозова Т., Логинов А. Рейдерство в России и за рубежом: сравнительный анализ // Рынок ценных бумаг. 2007. № 12. С. 63-75.

9. Шагиева Р.В., Букалерова Л.А. Единые государственные реестры как предмет посягательств при рейдерстве: проблемы теории и практики // Евразийский юридический журнал. 2012. № 8. С. 111-112.

\section{References (transliterated):}

1. Alekseev Yu.F. O rezul'tatakh raboty organov predvaritel'nogo sledstviya MVD Rossii po protivodeistviyu reiderskim zakhvatam // Nedvizhimost' i investitsii. Pravovoe regulirovanie. 2009. № 1. s. 11 // URL: http://dpr.ru/journal/journal_36_17.htm (data obrashcheniya: 26.10.2015).

2. Kuznetsova T.V. Nekotorye aspekty reiderstva // Tendentsii i perspektivy razvitiya ugolovnogo i ugolovno protsessual'nogo zakonodatel'stva $v$ bor'be s prestupnost'yu: Materialy Vserossiiskoi nauchnoi konferentsii, posvyashchennoi pamyati prof. B.S. Volkova. M.: RUDN, 2011. S. 111-116. 
3. Lapshin V.F. Prestupleniya protiv interesov investorov. M.: RIOR, 2014. 127 s.

4. Lapshin V.F.Ekonomicheskie i reiderskie prestupleniya: pravovoe soderzhanie i voprosy sootnosheniya // Rossiiskoe pravosudie. 2014. № 12. S. 82-88.

5. Lopashenko N. «Reiderstvo» // Zakonnost'. 2007. № 4. S. 7-12.

6. Mozheiko I.V. Piraty, korsary, reidery. M.: Avanta +, 2010. 416 s.

7. Slobodyanyuk D. Vladimir Putin predotvratil novuyu volnu «netsivilizovannogo zakhvata sobstvennosti» // Pravda. 2002. 6 avg. S. 5.

8. Tormozova T., Loginov A. Reiderstvo v Rossii i za rubezhom: sravnitel'nyi analiz // Rynok tsennykh bumag. 2007. № 12. S. 63-75.

9. Shagieva R.V., Bukalerova L.A. Edinye gosudarstvennye reestry kak predmet posyagatel'stv pri reiderstve: problemy teorii i praktiki // Evraziiskii yuridicheskii zhurnal. 2012. № 8. S. 111-112. 